\title{
Translating metaphors into Afrikaans in a source language- oriented translation of the Hebrew Bible
}

\author{
Christo H.J. van der Merwe and Elisabet Hendriks \\ Department of Ancient Studies, Stellenbosch University, \\ Private Bag X1, Matieland 7600. E-mail: cvdm@sun.ac.za
}

\section{Introduction}

How should metaphors be treated in a source language-oriented translation of the Bible with the following translation brief?

Create a source language-oriented translation of the Bible in idiomatic Afrikaans which can be read aloud and used in church services, but which is also suitable for catechism, Bible study and private use.

This paper aims to make a contribution towards addressing this question. Assuming that Gutt's (2000) notion of a 'direct ${ }^{1}$ or stimulus-based translation' embodies the skopos of this translation, our central hypothesis is that a basic insight into the cognitive mechanism of metaphors and their cultural embeddedness provides the key towards the development of a justifiable strategy for interpreting and translating metaphors in the above-mentioned type of translation. In this paper, we do not purport to provide a guide for the analysis and translation of all metaphors; we use merely one type of metaphor to illustrate (i) the cognitive processes typically involved when metaphorical language is used and (ii) some of the implications of these complex processes for the interpretation and translation of an ancient text like the Hebrew Bible. 
In order to better understand the problem to be addressed, we commence in Section 2 with a brief discussion of the background and theoretical frame of reference of the new translation of the Bible in Afrikaans (NBA). Some of the strategies proposed in recent years for dealing with metaphors in translating the Bible are discussed in Section 3. It will be evident from the theoretical frame of reference of the NBA why following these strategies is problematic as far as this translation project is concerned. As an interactional (and, by implication, an inferential) model of communication is assumed in this project, and many of the developments in cognitive linguistics are taken into account, ${ }^{2}$ recent insights into the cognitive mechanisms of metaphorical language are discussed in Section 4. ${ }^{3}$ The most pertinent of these insights are identified, and in Section 5 the implications they have for the NBA are spelled out in the form of a proposed strategy for treating metaphors. ${ }^{4}$

\section{The New Bible in Afrikaans}

Afrikaans is one of the 11 official languages of South Africa. It is a relatively young language with a colourful (although not always honourable) history. Currently, it is the mother-tongue of approximately 6 million people, with another 10 million secondary speakers. ${ }^{5}$ After initial attempts at translating the Bible at the end of the 19th century and in the early 1920s, the first "official" translation of the Bible in Afrikaans appeared in $1933 .{ }^{6}$ This word-for-word translation represents a translation from the Hebrew and Greek source texts, but followed the Dutch Statenvertaling as far as possible. The main reason for this strategy was an attempt not to "estrange" the target audience who were accustomed to the Statenvertaling (see Fensham 1974:62). The 1933 translation was revised in 1953. In 1983, a dynamic equivalent-inspired translation was published. In those apartheid days, the translation teams were predominately representative of the three "white" Reformed churches. This 1983 translation immediately became the official translation of the Bible in Afrikaans in these churches. However, this "Good News" type of translation did not appeal to all readers of the Bible in Afrikaans, including many in conservative Reformed and Pentecostal churches, the Roman Catholic Church and mother-tongue speakers who belonged to the coloured Reformed churches. ${ }^{7}$ This led to a situation in the 1990s in which one third of the Bibles in Afrikaans distributed by the Bible Society of South Africa (BSSA) were 1933/53 versions. In recent years, the BSSA has been advised by a committee, namely the Advisory Committee for the Bible in Afrikaans (henceforth "the Advisory Committee"), 
comprised of members from all the churches that use translations of the Bible in Afrikaans. This committee meets annually and, since the 1990s, the issue of a more source language-oriented translation which could replace the 1933/53 version has been on its agenda. On the recommendation of this committee, the BSSA organised a major conference in August 2001. The aim of this conference was to gather information about factors which may be relevant to a new translation of the Bible in Afrikaans. These included

(i) developments in the fields of translation studies and Bible translation, e.g., process models such as that of Christiane Nord (1997), which highlight some aspects of the inadequacies of Nida's product-oriented linguistic approach; Gutt's (2000) perspective on Bible translation as an instance of very difficult communication; and the frames model referred to in Wilt (2003);

(ii) developments in the study of the source languages;

(iii) theoretical and practical lessons to be learned from the New Dutch translation;

(iv) the development of Afrikaans as a language; and

(v) trends in Bible translation on the continent of Africa. ${ }^{8}$

One of the direct outcomes of this conference was an assignment in November 2001 by the Advisory Committee to scholars at four South African universities, namely the Universities of the Free State and Pretoria, Stellenbosch University and the Northwest University. This assignment was to prepare four types of translations, ${ }^{9}$ viz.

(i) Version 1, a translation with a highly concordant and source language orientation, while retaining the source language idiom;

(ii) Version 2, a translation in simple, flowing and clear language, meant as a reading Bible for the broadest possible spectrum of users, concordant where serviceable and dynamic where necessary;

(iii) Version 3, a translation meant for reading aloud during public worship, for catechism and for Bible study, with particular attention to the literary quality; and

(iv) Version 4, a linguistic revision of the 1983 translation. ${ }^{10}$

In 2003, after a cooperative venture by all four academic institutions, two types of translations were prepared for the Advisory Committee, viz. a Version 2 and a Version 3. ${ }^{11}$ Each translation type was formulated in terms of a clear translation brief. The concept of a 'translation brief' plays a central role in the functionalist model of Nord, and its utilisation is the outcome of the efforts of scholars from Stellenbosch University 
and the University of the Free State. Nord's functionalist model was identified by scholars from these institutions as a justifiable theoretical frame of reference for identifying, negotiating and documenting all the variables to be taken into account when embarking on a translation project (see Basson 2002 and Van der Merwe and Basson 2003). In November 2003, the Advisory Committee requested the BSSA to go ahead with the making of a source language-oriented translation of the Bible. After in-depth negotiations between representatives of all churches concerned, the translation brief was (re-)defined as follows:

Create a source language-oriented translation of the Bible in idiomatic Afrikaans which can be read aloud and used in church services, but which is also suitable for catechism, Bible study and private use.

In working out the details of the above-mentioned translation brief, it became evident that Nord's model requires a skopos to act as guideline when working out the details of a particular translation project. We are of the opinion that, although Gutt's notion of a 'direct or stimulus-based translation' may be regarded as an impractical theoretical construct, it embodies all the ideals of the above-mentioned translation brief. $^{12}$ Furthermore, since the concept is grounded in a well-recognised model of communication (see Van der Merwe and Winckler 1993), and shares many of the assumptions of recent cognitive approaches to the study of language, we hypothesise that it provides a better heuristic device than any other (of which we are aware) to act as the skopos of the NBA.

Against the above-mentioned background, it is obvious that, for the purposes of this investigation, the question "How should metaphors be treated in a source-oriented translation of the Bible?" is in essence the same as "How should metaphors be treated in a direct or stimulus-based translation of the Bible?"

\section{Current strategies}

If one considers translations of the Bible and/or consults the literature in the field of Bible translation, it becomes evident that a variety of strategies for dealing with metaphors are possible, ${ }^{13}$ viz. 
(i) The metaphor is retained in the target language. ${ }^{14}$ This happens in cases where the topic and the image or vehicle are well known to both the source and target language cultures, e.g., "The Lord ... is my shield" (Ps 18:3).

(ii) The metaphor is retained, but also further described in the target language. For example, Ps 23:5 literally reads "You make my head fat with oil"; the TEV translates this as "You welcome me by pouring ointment on my head".

(iii) The metaphor is translated as a simile. If the source text literally reads "... the LORD God is a sun and shield" (Ps 84:11), this clause is rendered (by the CEV, for example) as "Our LORD and our God, you are like the sun and also like a shield".

(iv) The source language metaphor is replaced with a "standard" equivalent in the target language. In Luke 13:32, Herod is described as a fox. Calling Herod "a fox" indicates that he was a cunning and sly person. In Swati, a cunning and sly person is normally described as a snake. Hence, Herod is called "a snake" in the Swati translation of Luke 13:32. ${ }^{15}$

(v) The metaphor is paraphrased. The 1983 Afrikaans translation of Ps 7:11 represents a paraphrase of the shield metaphor involved. Literally, the text could be rendered as "My shield is with God who saves the upright in heart". The 1983 Afrikaans Bible translates the sentence as the equivalent of "God, who helps the righteous, is my protector".

(vi) The metaphor is omitted. This means that if the source text reads He is a snail; he always walks slowly, the target text is translated as He always walks slowly.

None of the above-mentioned strategies is necessarily an ad hoc attempt to make the source text accessible to readers of a meaning-based translation. In other words, it might be possible to defend the merits of each in terms of that which a particular translation aims to accomplish. However, not one of strategies (ii)-(vi) (or even a combination of two or more of them) guarantees an adequate representation of the metaphor involved for our purposes, viz. the ascriptive metaphor God is a sun. The reasons for this will be evident from our discussion in Section 4. Of importance for the purpose of this paper is the following question:

How does one treat metaphors in a source-orientated translation, when retaining the literal sense of the metaphor may render a translation that is unintelligible for 
its readers (e.g., "The LORD is my chosen portion and my cup" Ps 16:5) or may give rise to misunderstandings (e.g., "For the LORD God is a sun" Ps 84:11)?

\section{The cognitive mechanism of metaphorical language}

It is beyond the scope of this paper to provide an exhaustive description of the cognitive mechanism of metaphorical language. ${ }^{16}$ In addition, the important issue of how to recognise and analyse various types and/or clines of metaphorical language is not dealt with here. ${ }^{17}$ Rather, we focus on those insights that illustrate conclusively that metaphorical language is a form of language which pervades all forms of human language, and that understanding its working and cultural embeddedness is crucial for determining a strategy to meet the requirements of the NBA's translation brief. For these purposes, we first give a brief overview of those perspectives on metaphors which most probably influenced the misconception that metaphors can, if necessary, be treated as similes or paraphrases, and then we proceed to more recent insights into the conceptual realities of metaphor. Next, we illustrate, by means of a prototypical "ascriptive" type of metaphor, why metaphors can be regarded as the resultant blend of the input from (at least) two conceptual domains. Thirdly, while accepting the notion that this process of conceptual blending underlies the development of human language, we illustrate why Lakoff and Johnson's (1980) notion that 'metaphors are things we live by' cannot be refuted. A brief summary of the insights gained into the cognitive complexities of metaphorical language concludes this section.

\subsection{Traditional perspectives on metaphor $^{18}$}

The view of metaphor as comparison dates back to Aristotle. According to this view, a metaphor is an abbreviated simile, in other words, a simile without like or as, and understanding metaphors is based on a real or a perceived similarity between two entities which are not normally associated with each other. This is probably still the most widely held view of metaphor today.

Another view of metaphor (the so-called "substitution view"), which is often associated with the comparison view, is that it represents an ornamental use of language. According to this view, a metaphor can be replaced by literal expressions without the loss of any information. 
According to the romantic view, "metaphor forms the very heart of language, thought and feelings, and literal language is a derived form of language"; furthermore, meanings generated by metaphor are "primarily emotive and evocative" (Kroneman 2004:35). Although this emphasis on the emotive quality of metaphor may create the impression that the romantic view could have reinforced the idea that metaphor merely represents an ornamental use of language, the romantic view also regards metaphor as a linguistic means of bringing together diverse thoughts to provide a fresh look on reality. According to Kittay (1989:6 as quoted in Kroneman 2004:35), this insight was the precursor of the interactive view.

\subsection{The interactive view of metaphor}

According to the interactive view developed by Black (1962) borrowing from Richards (1936), a metaphor is the outcome of the interaction of two entities and their conceptual worlds. The sum of the meaning produced goes beyond anything a literal statement can produce. The e fact that two entities and their conceptual worlds are involved implies that the general knowledge of native speakers comes into play in the use and interpretation of metaphors. This knowledge is embedded in the cultural system of the native speakers; in other words, it is not what the entities really are that comes into play, but how they are perceived by a specific language community. For example, it is irrelevant whether a fox is a cunning animal; what is relevant is whether the language community perceives a fox to be cunning.

Black (as referred to by Kroneman 2004:38) distinguishes between extinct, dormant and active metaphors. These distinctions correlate with Goatly's (1997:14-38) dead/lexicalised, inactive and active metaphors. Dead metaphors are instances where expressions (such as a red herring) have become part of the lexical stock of a language. Native speakers will recognise them as metaphors only if they know the etymology of the expressions. Inactive metaphors, which may range from "sleeping" to "tired", will often only be readily understood by native speakers if explained to them. Goatly (1997:32) regards the following as instances of sleeping metaphors: leaf as "foliage" and "page of a book", and crane as "species of bird" and "machine for moving heavy weights". Examples of tired metaphors are fox as "a cunning person", and cut as "budget reduction". 
A feature of both dead and inactive metaphors is that they tend to have a fixed conventionalised meaning. In contrast, in the case of active metaphors (in the words of Goatly 1997:35), "various associations of the Vehicle are selected on the basis of the Topic and the surrounding co-text." Goatly (1997:35) uses the following examples to illustrate how different topics and contexts may activate different aspects of the semantic potential of a vehicle or image used in a metaphor (in these cases, sewer): The kidneys are the body's sewers and A psychologist who threads the foul sewers of human despair. Another significant characteristic of active metaphors is that they are, as a rule, readily understood by native speakers.

Although the comparison, substitution and romantic views of metaphor may be applicable to some instances of metaphor, in our view the interactive view represents a major step towards a more comprehensive theory of metaphorical language. ${ }^{19}$ This understanding of the cognitive mechanism of metaphors has significant implications for Bible translation. It establishes conclusively that metaphors are a form of language use which cannot be explained by the use of literal language. This implies that when a metaphor is paraphrased, one or more aspects of the meaning to be conveyed may be lost.

Note that, according to Kroneman (2004:40-41), the interactive view also has its limitations. For example, it focuses on linguistic metaphors without taking into account the predetermined conceptual world which licenses and motivates the use of entities of conceptual source domain A to understand entities of a target domain B (see Kövecses 2002:110). The conceptual view of metaphor which addresses this "predetermined conceptual world" is the topic of the next sub-section.

\subsection{The conceptual view of metaphor ${ }^{20}$}

According to Lakoff and Johnson (1980), metaphors are not a matter of extraordinary language use. The essence of a metaphor is "understanding and experiencing one kind of thing in terms of another" (1980:5), and this is primarily how humans think when they use metaphors. This "way of thinking" is systematic and embodies the way in which humans experience themselves and their environment, e.g., HUMAN BODIES ARE CONTAINERS, EMOTIONS ARE FLUIDS, etc. These abstract or conceptual metaphors are seldom linguistically expressed, but each can motivate a range of linguistic metaphors, 
e.g., I blew my top; It boiled inside me; I poured out my love to her, etc. ${ }^{21}$ Furthermore, apart from the conventionalised metaphors, active metaphors (i.e., those associated with creative writers or poets) "are based on everyday conventional metaphors" (Kövecses 2002:46). ${ }^{22}$

Some conceptual metaphors, e.g., HUMAN BODIES ARE CONTAINERS, tend to occur across cultures, whereas others are culture-specific, e.g., HEAVENLY BODIES ARE GODS. ${ }^{23}$ Lakoff and Johnson (1980:22) state that "the most fundamental values in a culture will be coherent with the metaphorical structure of the most fundamental concepts in the culture." In other words, although the conceptual view of metaphors does not necessarily help one to understand the use of a Biblical Hebrew linguistic metaphor $x$ in a context $y$, this perspective on language provides a window, via the conceptual metaphor instantiated, on the conceptual world of speakers of the language. Apart from the invaluable insight into the conceptual world of the Bible, this type of insight is crucial for determining instances where the cultural differences between the world of the Bible and that of speakers of Afrikaans may cause a misunderstanding or a complete lack of understanding.

Up until now, our discussion has been fairly theoretical. In the next sub-section, we will use a practical example to illustrate the most relevant of the practical implications of the above-mentioned insights into the mechanisms and cultural embeddedness of metaphors. We will also introduce the notion 'conceptual blending', a notion which may be regarded as a further development or even logical consequence of the conceptual view of metaphor.

\subsection{The interactive view supplemented by the conceptual view and the notion 'conceptual blending'}

In terms of the interactive view, in the ascriptive type of metaphor ${ }^{24}$ (such as God is a sun), two entities with their associative conceptual worlds (or conceptual domains) interact with each other on the basis of some type of analogy between the two entities. In this example, God is the topic and sun is the vehicle. ${ }^{25}$ For speakers, the vehicle is typically the more concrete, more experienced or better known entity. The analogies between the topic and vehicle may arise on the basis of the physical features ${ }^{26}$ of the entities or the functions ${ }^{27}$ which they perform, as illustrated in the following diagram. 
As was said earlier, these analogies may be real or they may represent the perceptions and beliefs of a particular culture. ${ }^{28}$

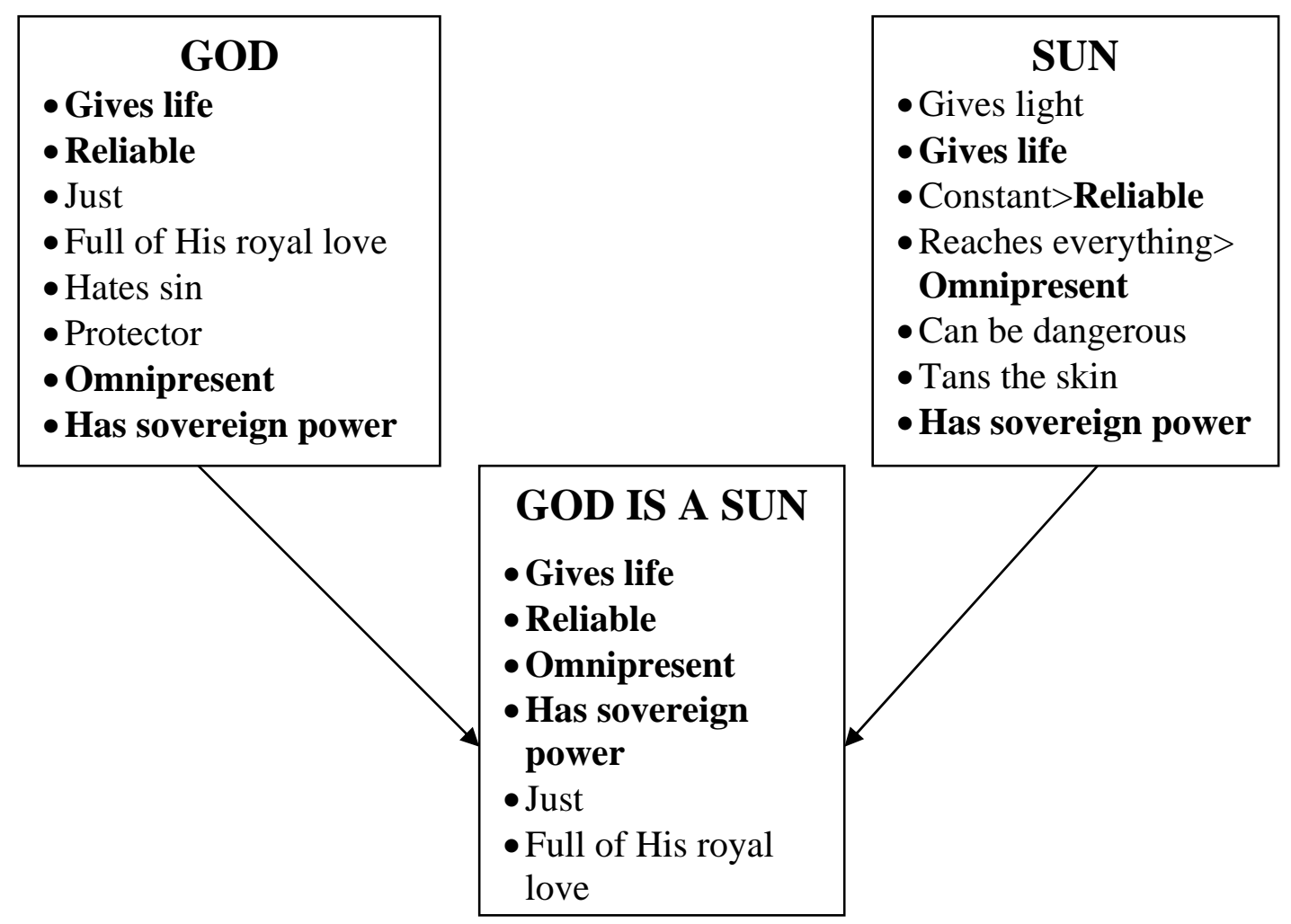

The result of the interaction between the two entities and their cognitive domains reveals some aspects of the topic. However, between the topic and the vehicle there may be a number of possible analogies that can be used for these purposes (as indicated by the expressions in bold in the diagram above). These analogies represent the semantic potential of the metaphor. ${ }^{29}$ In a specific context, only some of the analogies may be activated, or some may be more active than others. In the context of Ps 84:11 ("God is a sun and a shield"), the vehicle shield is used alongside sun. It can therefore be argued that, in the context of a second vehicle or image of God as protector, the following aspects of the semantic potential of sun as vehicle are dominant: reliability, sovereign power and omnipresence. $^{30}$

This underdeterminacy of a metaphor mainly applies to active metaphors, since the more conventionalised a metaphor becomes, the more limited its semantic potential. The tired metaphor He is a fox is a good example. ${ }^{31}$ Problematic in this regard for Bible 
translators is that it is not always certain where a Biblical Hebrew metaphor lies on the continuum from dead to inactive and active.

The conceptual view of metaphor underlines the fact that not any two entities can be related. A conceptual metaphor or cultural model ${ }^{32}$ has to sanction or motivate the process. For example, in the case of God is a sun and a shield, the sanctioning conceptual metaphors would be GODS ARE HEAVENLY BODIES and GODS ARE WARRIORS. $^{33}$

If the conceptual view has broadened our scope from a focus on linguistic metaphors to one on conventionalised metaphors and the conceptual metaphors which motivate them, the notion of 'conceptual blending' takes us one step further. It models in more detail the interaction that takes place when a conceptual domain A interacts with a conceptual domain B, domains A and B being regarded as mental spaces. ${ }^{34}$ Each of these mental spaces provides input to a mental space C, the resultant blend. Input A (e.g. 'God') and input B (e.g. 'sun') may contribute in various ways to the resultant blend. This process, however, takes place only because the blend has been licensed by a more generic mental space which was shared by 'God' and 'the sun', viz. that both are powerful and lifegiving entities. The metaphor God is a sun, in a sense, represents an oversimplification of metaphorical language, because Ps 84:11 actually reads "God is a sun and shield." This illustrates the fact that a blend may involve more than just the input of two domains and a single blend; rather, it possibly involves multiple blends. Consider the number of blends involved in the following example: It is clear that there are loopholes in the US immigration law big enough to drive a jet plane through.

Fauconnier and Turner (2002), in a publication with the illustrative title The way we think. Conceptual blending and the mind's hidden complexities, claim that the process of conceptual blending does not only explain how metaphors, similes and metonymy work, but also provides insight into the way in which semantic units in human language developed. ${ }^{35}$ It is beyond the scope of this paper either to fully explain this model or to defend its merits, ${ }^{36}$ such as that the notion of 'conceptual blending' does explain why and how specific blends become conventionalised. ${ }^{37}$ However, what is relevant for the purposes of this paper is that the notion of 'conceptual blending' provides further evidence of the embeddedness of metaphoric language in conceptual frames. Aspects of 
these frames are carried over into the resultant blends, i.e., specific instances of metaphorical language. This is why the meaning of these metaphors often cannot be reduced to a single element of propositional meaning which a translator can paraphrase or rephrase by means of a literal expression in the target language. ${ }^{38}$

\subsection{In conclusion: what insights have we gained into the workings of metaphors?}

The first insight gained into the workings of metaphors is that metaphors represent the results of a blend or multiple blends of entities from different conceptual domains, in which one kind of thing is experienced or understood in terms of another.

Secondly, in the broadest sense, the process of conceptual blending undergirds the development of semantic units in human language. In other words, the same processes that can be used to explain the polysemy of lexical entities underlie those of figurative language (in particular simile, metaphors and metonymy). This implies that metaphors, like lexical items, have a semantic potential of which specific dimensions are activated in specific contexts.

Thirdly, an abstract system of conceptual (and constitutive ${ }^{39}$ ) metaphors motivates the above-mentioned blending processes. Whether these conceptual metaphors are constitutive of cultural models or merely reflect them is still being debated. What we do know is that they embody both universal and culture-specific experiences of prototypical scenarios of language communities.

Another insight gained is that conceptual metaphors themselves are seldom expressed linguistically. However, they are instantiated by a range of linguistic metaphors. These linguistic metaphors represent a continuum ranging from lexicalised semantic units and dead metaphors to inactive and active metaphors.

Lastly, the semantic potential of metaphors at the "active" pole of the continuum should prototypically be activated to a larger degree by the contexts in which they are used. The semantic potential of those at the "conventionalised" pole will tend to be restricted by the language communities' shared understanding. 
What do the above-mentioned insights imply for the NBA with its specific skopos? In a sense, the answer is simple: The metaphors must be retained. A major challenge, however, is posed by the following question:

When is which type of information needed for bringing the conceptual world of target language audience in line with that of the source language culture to such a degree that they can understand the metaphorical language used?

\section{Proposed strategy for treating metaphors}

The purpose of this proposed strategy is not to act as a recipe which needs to be followed step-by-step. Rather, it represents hypotheses concerning the types of information that need to be considered when interpreting and translating metaphors. Furthermore, it assumes an idealised situation in which co-textual and contextual information is readily available and/or unproblematic, which is often not the case with the Hebrew Bible. It is envisaged that formulating a strategy like this could contribute to sensitising exegetes and translators to some of the most crucial factors that need to be considered when one wishes to bring the conceptual assumptions of the target text audience more in line with those of the source language culture. The proposed strategy entails the following:

(i) Exegetes or translators must inform themselves of the conceptual world of the source language in general, but also in particular of the conceptual models, ${ }^{40}$ cultural exemplars ${ }^{41}$ and/or cultural schemes ${ }^{42}$ underlying or reflected in both the topic and the vehicle of a metaphor. This process is imperative, irrespective of where on the continuum from lexicalised to active an instance of metaphorical language is situated.

In the case of God is a sun, this requires an insight into the way in which the people of Biblical times, or at a particular point in those times, thought about and experienced God and the sun. This differs substantially from that of people of today and from that of our source text audience. This is, of course, a tall order, since not all the authors, redactors and/or audiences of the Hebrew Bible necessarily shared the same conceptualisation of God or the sun. More important, though, are the differences in this regard between the source language and target audience text under consideration. 
Equally problematic are cases where the target audience assumes that they fully understand a source language vehicle. For example, as regards The Lord is my shepherd, few members of our target audience understand exactly how shepherds in Old Testament times tended to their herds. And it is precisely this activity which embodies the semantic potential of this metaphor. ${ }^{43}$

(ii) The position of a metaphor on the continuum from lexicalised to active must be established. Insights into the conceptual world referred to above need to be complemented by a study of the distribution and use of a specific metaphor. ${ }^{44}$ When the same topic and vehicle are used often, the chances are good that a conventionalised metaphor is involved.

(iii) On the basis of the contextual and co-textual information gathered at this point, the semantic potential of the conventionalised metaphor has to be determined. Each co-text, however, will suggest which aspect(s) of a metaphor's semantic potential has been activated in a specific context.

(iv) In the above-mentioned processes, the syntactic structure of a metaphor needs to be considered. This is important, since in Biblical Hebrew the features of a lion are often attributed God, but He is never called "a lion". In other words, characteristics of a lion are used as a vehicle for describing features of God, but never by means of an ascriptive type of metaphor. ${ }^{45}$ Furthermore, in contrast to custom in the Ancient Near East, characteristics of a lion are seldom used as a vehicle to describe an attribute of a king of Israel (see Strawn 2005:236-250). The explanations for this are without doubt important for bringing the conceptual world of our target language audience more in line with that of the source language culture.

(v) In the final analysis, the socio-cultural status of a literal translation of the metaphor into the target language needs to be determined. In other words, one needs to establish whether it is culture affirming, culture challenging, iconoclastic or culturally strange in the target language culture. Such an identification of, and comparison with, the metaphor's status in the target language culture will make it easier to anticipate the way in which the literal retention of the metaphor in the translated text will be problematic. Whenever possible, it could be helpful to determine at this stage the conceptual metaphor or range of conceptualised metaphors underlying a metaphor in the target language compared to that of the source language culture. In the case of "The Lord is my 
strength and my shield" (Ps 28:7), it could be argued that the conceptual metaphor LIFE IS A STRUGGLE/BATTLE is present in both the source and target language cultures.

The procedure in (v) above will shed light on whether the metaphor is universal, culturally overlapping or culture-specific. When translating from one language to only one other language, it is irrelevant to determine whether a metaphor is universal. More relevant is whether the metaphor is culturally overlapping or culture-specific.

The degree of cultural overlap may vary. Each metaphor must be dealt with on its own merits. In the case of "God is my shield" in Ps 28:7, the cultural overlap is so great that no additional information is required when retaining a literal translation of the metaphor. However, if the degree of overlap is less, as in the case of the shepherd metaphor in Ps 23, the following type of information is required in order to fully understand the literal translation of the metaphor:

In Syro-Palestine, sheep and goats were dependent on their shepherds. Shepherds, who could be men or women, always walked out in front of their herds. The herd, knowing the shepherd's voice, followed him/her everywhere. The shepherd had to take care of the feeding and watering of the herd and had to provide shade and protection for the herd.

In the case of a culture-specific metaphor, like the one encountered in Ps 75:11 ("All the horns of the wicked I will cut off, but the horns of the righteous shall be lifted up"), the conceptual world of the target language audience must be broadened so that they can understand the metaphor. The following type of information is then required:

The horns of some animals are their most important weapon, but also function as an adornment. The size and condition of the horns typically signalled the power, status and health of the animal. In this way, horns became the symbol of power and status in the Syro-Palestine culture.

In the case of Ps 39:13 ("Hear my prayer, O Lord, and give ear to my cry.... For I am a stranger with You, A sojourner like all my fathers"), a culture-specific metaphor 
requires the broadening of the conceptual world of the target language audience along the following lines:

Sojourners in the Ancient Near East and in Syro-Palestine did not have any rights when they were in a foreign country or region. They were entirely dependent on the leader of a clan or city to take care of their interests.

\section{Conclusion}

The focus of this paper was the treatment of metaphors in a translation with a translation brief which implies that the relevant communicative clues of the source language text must be retained. It is suggested that this nearly impossible task (which is an instance of difficult secondary communication) might be approached by taking the following into consideration:

(i) Metaphorical language pervades most forms of language use. In other words, metaphors are not restricted to the language of creative writers and poets.

(ii) This form of language is the result of the blending of two (or more) concepts, each with its own associated conceptual world. The resultant blend, the output, is as a rule more than the sum of the input.

(iii) Metaphorical language is deeply culturally embedded. Since the conceptual worlds of the Biblical Hebrew and Afrikaans cultures are not aligned, the chances for misunderstanding the Biblical Hebrew metaphors are often great. This happens, for example, when the socio-cultural status of the translated metaphor in Afrikaans overlaps only partially or not at all with that of Biblical Hebrew. In such cases, the conceptual world of the Afrikaans reader needs to be brought closer to that of the Biblical Hebrew writer by means of additional information (e.g., in the form of footnotes, endnotes, maps, etc.).

(iv) Metaphors constitute a continuum from dead to active (novel) metaphors. However, it is often not clear where on this continuum a Biblical Hebrew metaphor lies.

(v) The relationship between fixed expressions, idioms and metaphors is often not clear.

This exploratory study used one of the simplest types of metaphor, viz. ascriptive metaphor, as point of departure to illustrate the complexity and cultural embeddedness 
of metaphorical language. The examples used cannot be regarded as representative of metaphorical language in Biblical Hebrew. Therefore, it cannot be claimed that the strategy proposed in Section 5 is adequate for treating all types of metaphors in the Hebrew Bible. Nevertheless, this paper provides insight into metaphorical language and the problematic aspects thereof in Biblical Hebrew. It is not unreasonable to expect that these insights would be useful in the classification, analysis and interpretation of other types of metaphorical language in the source text of the Hebrew Bible. 


\section{Notes}

1. According to Gutt (2002:171), "a receptor language utterance is a direct translation of a source language utterance if and only if it purports to interpretively resemble the original completely in the context envisaged for the original". A direct translation of a receptor language is also referred to as a "stimulus-based translation", since it aims to retain all the communicative clues of the original.

2. See Tuggy (2003) for a discussion of the implications of developments in the field of cognitive linguistics for the "literal-idiomatic Bible translation" debate.

3. Schaeffner (2004) discusses some ("more general") implications of a cognitive approach to metaphor for translation studies.

4. In this paper, only metaphors in the Hebrew Bible are dealt with. It is assumed that most of the insights gained will also be applicable to translating metaphors in the Greek New Testament.

5. For more background information on Afrikaans, see http://en.wikipedia.org/wiki/ Afrikaans_language

6. For a brief overview in this regard, see Van der Merwe (2001).

7. See Payle's (2000) critique of the 1983 translation.

8. For the proceedings of this conference, see Naudé and Van der Merwe (2002).

9. For a report on the details of this project at Stellenbosch University, see Van Rensburg (2005).

10. The following selection of texts was used: Exod 33, Ps 16, Isa 1, Mat 5:1-20, Rom 7:7-26 and Rev 4.

11. The same texts as those in the 2002 project were translated. 
12. Although made from a different perspective, Chesterman's (2004:71) observation that "we need to understand to what extent relevance theory and skopos theory are saying more or less the same thing but within different frameworks" implies a possible compatibility of insights from relevance theory with those of our functional frame of reference.

13. These strategies were gleaned by Hendriks (2006:33-35) from the works of De Waard (1974), Newmark (1980, 1982), De Blois (1985) and Hermanson (1999).

14. According to Beekman and Callow (1974:145), "the first approach is to retain the form of the metaphor ... If this is inadequate, then the form of a simile is tried. If this still fails to communicate, then a nonfigurative form is used".

15. According to Hermanson (1999:239-240), this translation did not have the "expected effect" among the Swati audience.

16. For this purpose, consult Goatly (1997), Kövecses (2002) and Kroneman (2004).

17. See Steen $(1994,2004)$ in this regard.

18. See Goatly (1997:116-119) for a succinct overview and Kroneman (2004:29-47) for an exhaustive survey of the theories of metaphor. This sub-section relies heavily on Kroneman (2004).

19. Goatly (1997:118-119) is of a different opinion. He prefers a sophisticated version of the comparison view. According to this view, similes and metaphors are interpretatively equivalent. He concedes that similes cannot always be used to make the same assertion or cannot always have the same effects as metaphors. This is exactly what Pohlig (2006) illustrates by comparing the use of metaphors and similes in the book of Hosea.

20. The basic tenets of the conceptual view of metaphor are described in Lakoff and Johnson (1980). Kövecses (2002) provides a brief, but fairly comprehensive, 
introduction to most of the insights gained in the subsequent debate on the conceptual nature of metaphorical language use.

21. These conceptual metaphors represent what Lakoff and Johnson (1987:68) calls "Idealized Cognitive Models" (ICMs). According to Pohlig (2006:10), "the ICM corresponds to a great degree to what people call a commonsense view of reality, and as such a folk theory (Lakoff) or a cultural model (Quinn)". For a more detailed discussion in this regard, see Pohlig (2006:10-14).

22. Kövecses (2002:47-49) lists the following types of active metaphors that appear in literature: (i) poetic reworking of ordinary metaphors, which could be extending, elaborating, questioning or combining ordinary metaphors; (ii) personification; (iii) image metaphors; and (iv) megametaphors.

23. See Kövecses (2002:163-182) on the universality of conceptual metaphors and (2002:183-198) for cultural variations of metaphors.

24. "Ascriptive type of metaphor" refers to metaphors in which the topic is specified in a copula construction, such as God is a sun. For a detailed treatment of ascriptives, see Goatly (1997:205-206). For an overview of the various means of topic specification, e.g., copula constructions, apposition, genitives, premodification, compounds, blends and topic specification across parts of speech, see Goatly (1997:198-228).

25. For a discussion of the meta-language used by different scholars, see Hendriks (2006:18-20).

26. Ps 29:5-6 reads: "The voice of the LORD breaks the cedars; the LORD breaks the cedars of Lebanon." Just as the cedars of Lebanon grew high and appeared to be strong and unassailable, so powerful people sometimes think they are mighty and unassailable. By analogy with the cedars, these powerful people (who often think they are accountable to nobody) stand out in their pride among their fellow men. 
27. In the case of the Lord is my shepherd, the analogy is functional. The functions which a shepherd fulfils in the life of his/her sheep are analogous to the functions the Lord has in the life of His people.

28. For the psalmist and his/her audience, the sun was a life-giving entity and a symbol of reliability and order. For the people of today, the sun is primarily a ball of fire around which the earth revolves.

29. For the notion 'semantic potential', see Van der Merwe (2006). This semantic potential may also be the "weak implicatures" referred to by Sperber and Wilson (1986). See also Gutt (2000:88-90).

30. The following translations illustrate the limitations of attempts to explicate the sun metaphor in Ps 84:11:

"The Lord God is our power and protector" [Afrikaans: "Die Here God is ons krag en ons beskerming" (1983 translation)]

"For the Lord is our sun that gives us light" [Afrikaans: "Want die Here God is ons son wat vir ons lig gee" (Die Lewende Bybel)]

"The Lord shows us what we must do" [Afrikaans: "Die Here wys vir ons wat ons moet doen" (Die Bybel in Hedendaagse Afrikaans)]

"For the Lord is our sovereign protector" (The NET Bible)

"For the Lord is our light and protector" (New Living Bible)

"The Lord is our protector and glorious king" (Good News Bible)

"For Yahweh is our rampart and shield" (New Jerusalem Bible).

31. Interestingly enough, the tired metaphor She is a bitch can refer to a woman who sleeps around or to one who tends to be unsympathetic and quick with harsh criticism, or it can be a general derogatory description of a woman.

32. The question whether conceptual metaphors undergird or merely reflect cultural models has been intensely debated in recent years. See Pohlig (2006:23-29).

33. For modern man, the heavenly bodies are not gods, but primarily entities that provide light. It is therefore not unexpected to find this cultural model to be 
reflected in some modern translations of Ps 84:11. See Die Lewende Bybel, Die Bybel in Hedendaagse Afrikaans and The New Living Bible in footnote 30.

34. Mental spaces are organised by Idealized Cognitive Models representing prototypical scenarios (Pohlig 2006:12).

35. According to Coulson and Oakley (2005), "conceptual integration, or blending, is a theoretical framework for exploring information integration that underlies the construction of meaning... Blending involves a set of operations for combining dynamic cognitive models in a network of mental spaces ... or partitions of speakers' referential representations".

36. Pohlig (2006:30-36) explains the notion 'conceptual blending' and points out its implications for studying figures of speech.

37. Grady (2005) argues for a set of primary metaphors which "do constitute a distinctive class of counterpart connections that require explanations not found among blending theory's other technical apparatus".

38. This is also the conclusion of Dagut (1976) in his publication Can 'metaphor' be translated?

39. For an explanation of the notion 'constitutive metaphor', see Pohlig (2006:14).

40. The model of "God as father" is based on the cultural scheme of fatherhood in Biblical times.

41. Olive trees and olive oil were symbols of prosperity, daybreak symbolised a time of salvation, an animal's horns were symbols of power and status, etc.

42. The cultural scheme of fatherhood, a husband, a shepherd, a lion and his behaviour, etc. 
43. For the above-mentioned purposes, current lexica are not very helpful, and Bible and theological dictionaries, Ryken, Wilhoit, Longman, Duriez, Penney, and Reid (1998) or other relevant monographs have to be consulted. Unfortunately, there has been relatively little systematic investigation of the conceptual metaphors reflected in the source language texts of the Bible. Insight into the universal and cultural specifics of the source language's conceptual metaphors would have been valuable for understanding the general system underlying the linguistic metaphors of these ancient languages.

44. Electronic libraries like Logos Library Systems (in particular The Stuttgart Electronic Study Bible) or other electronic tools like Bible Works or Paratext provide effective means to carry out sophisticated concordance searches online.

45. See footnote 24 .

46. For a definition and examples of each of these notions, see Kroneman (2004:6064) and Hendriks (2006:30-32). Hendriks adds the notion of 'culturally strange metaphor'. 


\section{References}

Basson, C.S. 2002. ' $n$ Funksionalistiese benadering tot Bybelvertaling [A functionalistic approach to Bible translation]. Master's thesis, Stellenbosch University.

Beekman, J. and J. Callow 1974. Translating the Word of God, with scripture and topical indexes. Grand Rapids, Michigan.: Zondervan.

Black, M. 1962. Model and metaphors: studies in language and philosophy. New York: Cornell University Press.

Chesterman, A. 2004. Where is similarity? In S. Arduini and R. Hodgson (eds.) Similarity and difference in translation: proceedings of the international conference on similarity and translation, New York, May 31-Jun 1 2001. Rimini: Guaraldi Press. pp. 63-76.

Coulson, S. and T. Oakley. 2005. Introduction. Journal of Pragmatics 37: 1507-1509.

De Blois, K.F. 1985. Metaphor in common language translations of Joel. The Bible Translator 36(2): 208-216.

De Waard, J. 1974. Biblical metaphors and their translation. The Bible Translator 25(1): 107-116.

Dagut, M.B. 1976. Can 'metaphor' be translated? Babel 22: 21-33.

Fauconnier, G.T. and M. Turner. 2002. The way we think: conceptual blending and the mind's hidden complexities. New York: Basic Books.

Fensham, C. 1974. Afrikaans en die kerk [Afrikaans and the church]. In B. Kok, F.C. Fensham, J.H. Senekal, H. Venter, en D.J. Viljoen (eds.) Afrikaans, ons pêrel van groot waarde. Johannesburg: Perskor. pp. 54-65.

Goatly, A. 1997. The language of metaphors. London: Routledge.

Grady, J. 2005. Primary metaphors as inputs to conceptual integration. Journal of Pragmatics 37: 1595-1614.

Gutt, E-A. 2000. Translation and relevance: cognition and context. $2^{\text {nd }}$ edition. Manchester: St Jerome.

Hendriks, L. 2006. Die vertaling van metafore in 'n brontaalgerigte Bybel in Afrikaans [The translation of metaphors in a source language-oriented Bible in Afrikaans]. Master's thesis, Stellenbosch University.

Hermanson, E.A. 1999. Herod is a fox. The Bible Translator 50(2): 235-240.

Kövecses, Z. 2002. Metaphor. A practical introduction. Oxford: Oxford University Press. 
Kroneman, D. 2004. The LORD is my shepherd. An exploration into the theory and practice of translating biblical metaphor. Ph.D. dissertation, Free University, Amsterdam.

Lakoff, G.J. and M. Johnson. 1980. Metaphors we live by. Chicago and London: University of Chicago Press.

Lakoff, G.J. and M. Johnson. 1987. Women, fire, and dangerous things: what can categories reveal about the mind. Chicago: University of Chicago Press.

Naudé, J.A. and C.H.J. van der Merwe (eds.) 2002. Contemporary translations studies and Bible translation: a South African perspective. Acta Theologica Supplementum, University of the Free State.

Newmark, P. 1980. The translation of metaphor. Babel 25: 93-100.

Newmark, P. 1982. Approaches to translation. Oxford: Pergamon.

Nord, C. 1997. Translating as a purposeful activity. Manchester: St. Jerome.

Payle, K. 2000. Ideology, politics and the Afrikaans Bible translation. Theologia Viatorum 26: 74-91.

Pohlig, J.N. 2006. A cognitive analysis of similes in the book of Hosea. Doctoral dissertation, Stellenbosch University.

Richards, I.A. 1936. The philosophy of rethoric. Oxford: Oxford University Press.

Ryken, L.W., J. Wilhoit, T. Longman, C. Duriez, D. Penney, and D.G. Reid (eds.) 1998. Dictionary of biblical imagery. Illinois: Intervarsity Press.

Schaeffner, C. 2004. Metaphor and translation: some implications of a cognitive approach. Journal of Pragmatics 36: 1253-1269.

Sperber, D. and D. Wilson. 1986. Relevance: communication and cognition. Oxford: Blackwell.

Steen, G. 1994. Understanding metaphor in literature: an empirical study. London: Longman.

Steen, G. 2004. Can discourse properties of metaphor affect metaphor recognition? Journal of Pragmatics 36: 1295-1313.

Strawn, B.A. 2005. What is stronger than a lion? Lion image and metaphor in the Hebrew Bible and the Ancient Near East. Fribourg: Academic Press.

Tuggy, D. 2003. The literal-idiomatic Bible translation debate from the perspective of cognitive grammar. In K. Feyaerts (eds.) The Bible through metaphor and translation. A cognitive semantic perspective. Oxford: Peter Lang. pp. 15, 239288. 
Van der Merwe, C.H.J. 2001. Is dit nou weer tyd vir 'n nuwe Bybel in Afrikaans? [Is it once again for a new Bible in Afrikaans?] Unpublished Manuscript. Stellenbosch.

Van der Merwe, C.H.J. 2006. Lexical meaning in Biblical Hebrew and cognitive semantics. Biblica (forthcoming).

Van der Merwe, C.H.J. and C.S. Basson 2003. 'n Nuwe vertaling van die Bybel in Afrikaans. 'n Teoretiese en praktiese oriëntering [A new translation of the Bible in Afrikaans. A theoretical and practical orientation]. Nederduits Gereformeerde Teologiese Tydskrif 44(3-4): 550-567.

Van der Merwe, C.H.J. and W. Winckler. 1993. Teaching tomorrow's Bible translators in the light of today's translations. Journal of Northwest Semitic Languages 19: 41-58.

Van Rensburg, A. 2005. 'n Nuwe vertaling van die Bybel in Afrikaans: 'n perspektief op die teorie en praktyk [A new translation of the Bible in Afrikaans: a perspective on the theory and practice]. Master's thesis, Stellenbosch University.

Wilt, T. 2003. Bible translation. Frames of reference. Manchester: St. Jerome. 